\title{
Converging paths of variation: Bilingual rhotics and language change in the Archipelago of San Andres, Colombia
}

\author{
Falcon Restrepo-Ramos \\ Minnesota State University \\ falcon.restreporamos@mnsu.edu
}

Received: 06-03-21

Accepted: 15-11-21

Published: 19-02-22

How to cite: Restrepo-Ramos, Falcon. 2022. Converging paths of variation: Bilingual rhotics and language change in the Archipelago of San Andres, Colombia. Isogloss. Open Journal of Romance Linguistics 8(1)/3.

DOI: https://doi.org/10.5565/rev/isogloss.115

\begin{abstract}
This study examines the acoustic realization of phonemic taps and trills across generations of Creole-Spanish bilinguals in the Archipelago of San Andres, Colombia. Formant frequencies in the form of F2 and F3 were compared in the realization of 1,450 rhotics presenting no lingual closure produced in the bilingual Spanish speech of three generations of Creole-Spanish speakers. Alongside, F2 and F3 values were extracted from rhotic segments produced in the monolingual varieties coexisting in the Archipelago, Islander Creole $(n=328)$ and Colombian Continental Spanish $(n=150)$. Results show that $\mathrm{F} 3$ frequencies and the distance between $\mathrm{F} 3-\mathrm{F} 2$ in senior bilinguals increasingly resemble the values in Islander Creole approximants, whereas younger generations are more closely associated to Continental Spanish. Supporting this trend is the fact that second generation speakers stand at an intermediate position between generations. These findings suggest a change in progress where approximants in younger generations are converging in the direction of Colombian Spanish, while formant frequencies in seniors are more associated with Islander Creole.
\end{abstract}


Keywords: zero-occlusion rhotics, sound variation, Islander Creole, Raizal Spanish, language convergence.

\section{Introduction}

In the Caribbean Archipelago of San Andres, Colombia, Spanish coexists with an English-based Creole known as Islander. This Archipelago is composed of a set of three islands located in the Southwestern Caribbean: San Andres, Old Providence, and Santa Catalina. This study examines the outcomes of language contact in terms of the variable production of bilingual rhotics produced with no lingual closure across generations of the local self-denominated Raizal ${ }^{1}$ communities. Little is known regarding the outcomes of contact at the generational level of bilingual speakers of an English-based Creole and the national language of Spanish in this part of the Caribbean, and this is particularly the case of bilingual rhotics in these island communities. The current study addresses this void in the field by examining the highly variable use of $/ \mathrm{r} /$ in the Spanish variety spoken by generations of bilingual Raizales emerged from extended contact between the monolingual Spanish and Islander Creole. This study examines zero-occlusion $/ \mathrm{r} /$ production across generations and its association with the languages in contact, as a window to the effects of language contact in the local communities of this Archipelago. This work begins with an introduction to the research site and a review of the literature on sound change and rhotic variation. Then, I introduce the methodology of the study. Next, I present the results of the analysis across generational groups of Creole-Spanish bilinguals, along with the converging patterns of variation between the languages in contact. Finally, I discuss the implications of the findings for the communities under study.

\subsection{The Creole Communities of the Archipelago}

The ethnolinguistic vitality of Raizales and their Creole language has changed dramatically during the last 100 years. At the beginning of the 20th century, it was estimated that a total of 8,000 Raizales lived in the Archipelago (Dittman, 1992). In 2005 the official number reached 23,396 (DANE, 2005). A new official census ${ }^{2}$ now estimates a population of 48,299 inhabitants for both established Colombian immigrants and Raizales. The commercial expansion of the islands in 1953 resulting from the freeport declaration brought an ever-increasing influx of business-oriented immigrants until restriction policies were put into place. Consequently, the old sites where Raizales have traditionally established their communities have now been displaced by hotels, an airport, and an array of multiple businesses. The conflict for land and means of living have displaced this community to live outside of the commercial spheres of economic and political significance of the islands, and settled in ethnic neighborhoods, where Islander Creole maintains oral transmission and community ascription. Both Raizal communities in San Andres and Old Providence have remained in close-knit communities somewhat distant from the fast-paced life of the urban area.

\footnotetext{
1 The ethnonym of Islander Creole speakers born in the Archipelago of San Andres.

A new census in 2018 has been implemented by the Colombian government (https://sitios.dane.gov.co/cnpv/\#!/)
} 
Old Providence presents a different sociolinguistic panorama mainly due to its distance from San Andres that has allowed Old Providence to be more culturally and linguistically preserved. There are 56 miles of maritime waters between them, and contrary to San Andres, Old Providence was not included in the expansionist commercial project of a duty-free port. Estimates place the population of Old Providence at 5,000 inhabitants, from which 89\% are composed of Raizales (Enciso-Patiño 2004). Official numbers seem to support this information with 3,645 Islanders accounting for $88 \%$ of the entire population, mostly living in rural areas (DANE, 2005). In a speech community of this size, it is safe to assume a greater maintenance of Islander Creole permeated less by the presence of Spanish in comparison to San Andres. In fact, speakers of Island Creole have far fewer daily interactions with Spanish speakers, due to more rigid protective measures against new immigrants, the insistence of the locals for their English legacy (Bartens, 2013), and the value of English as the international language of tourism (Flórez, 2006). As a result, Islander is still prevalent in most aspects of the lives of Raizales (Moya-Chaves, 2014; Bartens, 2013; Flórez, 2006; Bartens, 2002; Morren, 2001), and has helped to maintain the prestige on this Islander variety.

The main focus of this work involves the cross-examination of the Spanish variety spoken by generations of bilingual Raizales emerged from extended contact between Colombian Spanish and Islander Creole. In doing so, I distinguish two linguistic varieties spoken by the same Raizal population. The first variety involves the Raizal mothertongue: the English-based Creole, known as Islander Creole. The second variety correspond to the bilingual Spanish spoken by Raizal informants. This variety will be categorized as Raizal Spanish due to belonging to the Raizal ethnic group and will be used in this study henceforth. Raizal Spanish will be examined across three generations of speakers in both Islands of the Archipelago, San Andres and Old Providence (which includes Santa Catalina). In addition, Continental Spanish, the monolingual Spanish spoken by immigrants who arrived in the islands from coastal Colombia, will also be compared. In conclusion, the three linguistic varieties that will be examined in this study are: Islander Creole, Raizal Spanish, and Continental Spanish.

\subsection{Rhotic Variation and Sound Change}

In Spanish, rhotic sounds are contrastive in word-medial intervocalic contexts, and they are traditionally described as either alveolar taps or trills (Navarro-Tomás 1999; Hualde, 2005). In alveolar taps, the apical portion of the tongue bounces a single time against the alveolar ridge or palate, while alveolar trills require at least two of these articulatory gestures. When no vibration occurs, alveolar taps and trills are distinguished based on the phonotactics of the language and their duration. As a result, segmental duration has been used as a reliable measurement, perceptible enough to distinguish between taps and trills in monolingual and bilingual communities. For instance, Bradley and Willis (2012) investigated the variable production of the tap-trill contrast in the monolingual Spanish spoken in Veracruz, Mexico. The researchers found that many rhotic variants present reduction and elision of lingual closures, but those with a measurable contact are produced long enough to be distinguished as trills. While trills are produced with one or two lingual contacts and a post-approximant phase, most taps presented no lingual closures. Henriksen (2015) set out to investigate the neutralization of the tap trill contrast in a bilingual Spanish-English speech community in the area of Chicagoland. Results showed that the contrast was maintained by means of segmental duration. In another study measuring segmental duration between Spanish rhotics, Melero-García and Cisneros 
(2020) found that auditory perception of a trill /r/ was correlated with longer durational cues. In contrast, longer taps were more often perceived as /r/. Bilingual Spanish rhotics have also been studied in contact scenarios. Balam (2013) documented retroflex variants in Belizean Spanish in place of intervocalic trills. Likewise, it was found that the tap/trill contrast was mostly maintained by means of segmental duration, but neutralization occurred conditioned by the type of linguistic task conducted. Zahler and Daidone (2014) also documented zero-occlusion tap/trill variants in the Spanish of Málaga, Spain, whose production was conditioned by several linguistic factors, such as word position and lexical frequency.

The fact that the maintenance of the tap-trill contrast has received substantial attention in previous literature gives a hint to the ongoing sound change towards weakened and zero-occlusion variants. Zero-occlusion or approximant/assibilated allophones are in juxtaposition to canonical taps and trills and are increasingly being reported in many other Spanish varieties. A zero-occlusion rhotic is defined here as an innovative tap or trill that presents no single (in the case of taps) or periodic (in the case of trills) lingual closure(s) with the surface of the palate. Diaz Campos (2008) found that approximant variants are more common than trilled segments in the Spanish of Venezuela; Hammond (1999) found assibilated variants being predominantly produced in Argentina, Chile, Peru, and Puerto Rico; Willis (2006) examined pre-aspirated taps in the Spanish of Dominican Republic; and Colantoni (2006) revealed a continuum of fricative to approximant rhotics. A great deal of these allophones in Central American Spanish and certain Colombian Spanish dialects have been also documented. In a survey of rhotic production in Central and South American Spanish varieties, Bradley (2006) only found that $16 \%$ of syllable-initial tokens could be classified as trills (containing two lingual closures) in /sr/ clusters across word boundaries, and only one token presented the prescribed three lingual-contact closure. Colombian informants realized non-trilled variants in a 4 to 1 proportion compared to normative trills. From these, $60 \%$ percent constituted approximant realizations and another $20 \%$ fricative rhotics. Blecua (2008, 2001) has highlighted the great deal of variation of Spanish rhotics, which includes weakened zero-occlusion variants. These realizations appear more common than expected based on the description of standard phonetic textbooks (Hualde, 2005). This handful of studies demonstrate that Spanish taps and trills are increasingly being reported with variants that lack the articulatory gestures for single or periodic vibrations in both bilingual and monolingual Spanish varieties of Spanish.

What appears as a sound change in the Spanish language might be exacerbated by contact situations like the one present in the Archipelago, due to the convergence of different phonological systems. A language contact phenomenon corresponds to a situation in which languages coexists within the same space and are used concurrently in the same society at the same time (Thomason, 2001, p. 1; Klee and Lynch, 2009, p. 1). Expanding this basic definition, such conditions will imply situations of bilingualism, in which anyone who uses two languages for functional purposes regardless of proficiency is considered a bilingual individual (Thomason 2001, p. 3). In such scenarios, the languages in contact might exert an influence in the bilingual speech of these individuals and changes in the languages could arise. Phonological change in bilingual speech follow a trajectory in which phonetic variants gradually coincide with those allophones of the dominant language, which constitutes a case of phonological interference (Thomason, 2001; Winford, 2003). I will test this assumption with the analysis of formant frequencies in the zero-occlusion rhotics of the Archipelago. Formant trajectories have been used as 
reliable measurements for examining the phonetic properties of rhotic approximants in English, the main lexifier of Islander Creole. From these, the lowering of F3 has been shown to be the lowest between English sounds, which might be narrowly separated from F2 (Hagiwara, 1995; Kent and Read, 2002). A lower F3 is a representation of a resonance that indicates a maneuver involving the retraction of the tongue in the postalveolar region, while a lower F2 represents the constriction of the pharynx (Johnson, 2011). As such, the lowering of F3 frequencies and the shortening of the F3-F2 distance are reliable measures to identify an approximant retroflex rhotic (Espy-Wilson, 1992; Lehiste, 1964). In contrast, higher F3 values would represent a more fronted realization, closer to the alveolar ridge. When cross linguistically contrasting the acoustic nature of rhotics in Spanish and English, we encounter a clear way to distinguish both zero-occlusion rhotic segments and their distinct articulatory production in the figure of formant frequencies. Previous research has identified several formant frequencies as the best acoustic predictors for distinguishing zero-occlusion rhotic production in the linguistic varieties of the Archipelago of San Andres (Restrepo-Ramos, 2021). Precisely, the manner of articulation of these allophonic variants has been examined in detail in a previous study (Restrepo-Ramos, 2021) and it has been determined to conform to an approximant realization in both taps and trills produced with no lingual closures in Raizal Spanish. Thus, both the bilingual varieties and the contact languages are characterized by approximant rhotics when no lingual closure is present.

Therefore, the driving assumption on the distribution of approximant rhotics in the bilingual variety of Spanish spoken in the Archipelago involves the transfer of phonetic features in the bilingual speech that resemble those of the donor language. In other words, the realization of these bilingual rhotics in the vernacular speech will potentially correlate to instabilities in the production of rhotics across generations of Islander Creole speakers, constrained by different degrees of contact in the Archipelago. Specifically, young Raizal informants in San Andres might show signs of convergence more related to the monolingual Spanish variety. Old Providence, on the other hand, presents a different sociolinguistic situation, due to historical events that left this island out of the commercial expansion project of the mid-1950s. As a result, this Raizal community might exhibit a greater level of phonological interference from the L1 English-based Islander Creole. Regarding a similar contact situation, a retroflex rhotic variant has been documented in Belizean Spanish (Balam, 2013) and in Limon Creole/Spanish bilinguals (Zimmer, 2011). Precisely, previous research has established approximant rhotic realizations in Islander Creole constrained by different degrees of vocal tract openness (Restrepo-Ramos, 2019). Therefore, the variability of approximant rhotic production across generations of Raizal bilinguals merits further empirical analysis.

The research question guiding this study are the following:

1. Is there a change in progress in the approximant taps and trills across generations of Raizal Spanish speakers?

If there is a change in progress,

2. Is there any generation that converges in the direction of one of the languages in contact, either Islander Creole or Continental Spanish? 


\section{Methodology}

Data was collected from 30 Raizal locals residing in the Archipelago of San Andres. Speech data was elicited via sociolinguistic interviews and recorded using a Zoom H4N Pro sampled at $44100 \mathrm{~Hz} / 32$-bit and a Shure omnidirectional lavalier microphone with a mounted preamplifier. Sociolinguistic interviews were conducted in Spanish, lasted between 60 to 90 minutes, and covered a range of familiar topics for the informants, including work, education, family, life in the Archipelago, children, society, religion, and ethnic and territorial issues. Ages of the participants ranged from 18 to 89 years. Table 1 presents a description of the Raizal Spanish informants recruited for this study.

Table 1. Generations of Raizal Spanish informants.

\begin{tabular}{|c|c|c|c|}
\hline Generation & Age Median & Island & Sex \\
\hline 1st Generation & 72 & San Andres & 3 females, 2 males \\
\hline 2nd Generation & 46 & San Andres & 3 females, 2 males \\
\hline 3rd Generation & 28 & San Andres & 2 females, 3 males \\
\hline 1st Generation & 61.5 & Old Providence & 3 females, 2 males \\
\hline 2nd Generation & 43 & Old Providence & 3 females, 2 males \\
\hline 3rd Generation & 26 & Old Providence & 2 females, 3 males \\
\hline
\end{tabular}

As seen in Table 1, Raizal Spanish informants were divided by the island of origin, sex, and generational group. Figure 1 shows the locations where data collection took place in both San Andres and Old Providence.

Figure 1. Geographical distribution of the informants.

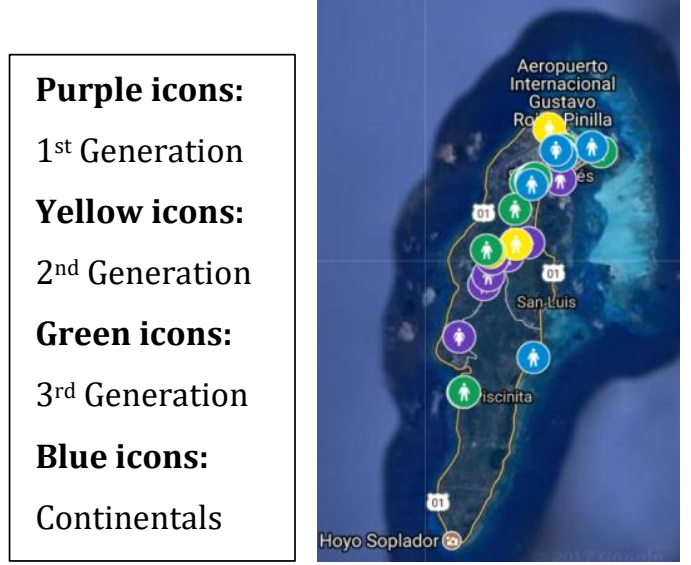

San Andres

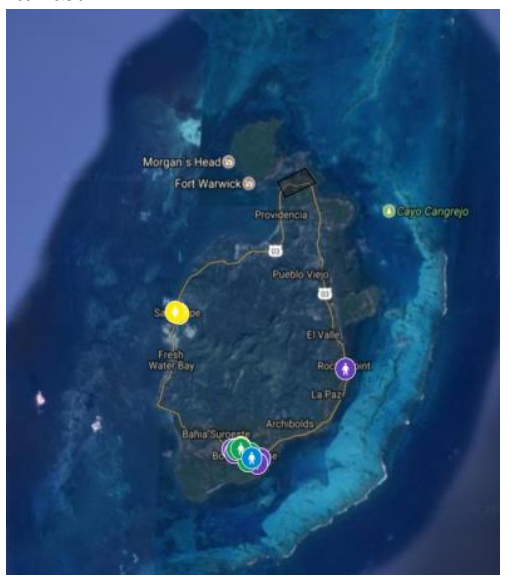

Old Providence and Santa Catalina

Speech data for Islander Creole were obtained from 5 Raizal informants who were asked to narrate the Frog story (Mayer, 1969) or recounted folk stories (i.e., Anansi stories). For Continental Spanish, five monolingual Spanish speakers, long-time resident of the islands and born in the Caribbean coast of Colombia were interviewed. For both Islander Creole and Continental Spanish informants, no generational classification was followed, as only representative samples of language were required to compare with Raizal Spanish. 
Before the analysis of the speech data could be conducted, several datasets were prepared for Islander Creole, Continental Spanish, and each generation of Raizal Spanish. In total 40 recordings were selected (Raizal Spanish $=30$, according to the generational groups in both islands, Islander Creole $=5$, Continental Spanish $=5$ ) for the analysis of approximant rhotics. For each recording, a transcribed sample of 15 minutes of speech was selected 15 minutes after initiated the recording. All zero-occlusion allophones appearing in each speech sample were extracted from the selection. This process was established in order to maintain a comparable extraction methodology per participant and per age group. Each individual token was visualized in a spectrogram and their phonetic boundaries were labeled and segmented in Praat (Boersma and Weenik, 2018). Figures 2 and 3 illustrate how tokens were observed and labeled in Praat compared to vibrant variants.

Figure 2. Tap with a normative lingual closure (left). Tap displaying no lingual occlusion (right).
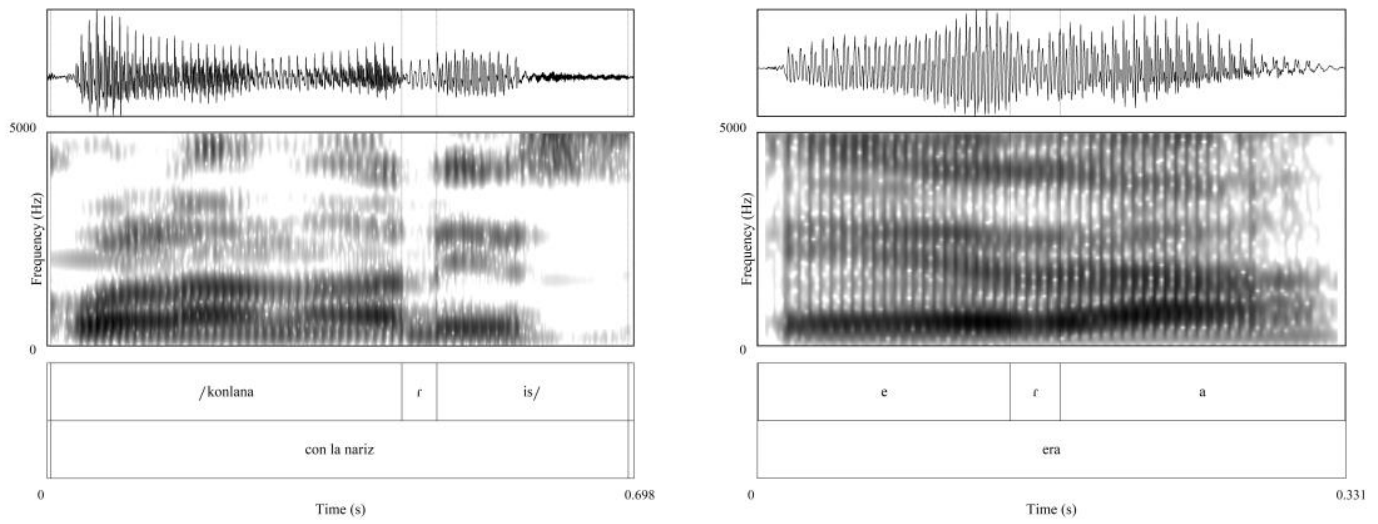

Figure 3. Trill with the normative lingual closures (left). Trill displaying no tongue vibration (right).
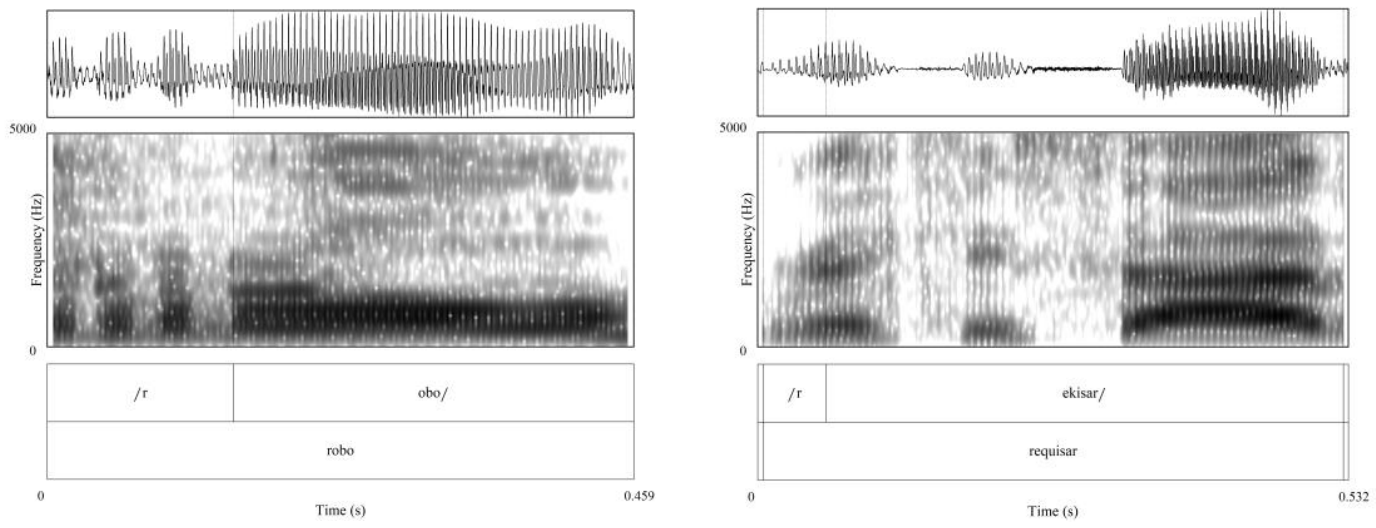

As seen in Figures 2 and 3, approximant phones were identified based on the absence of occlusion in the spectrogram, the continuity of the formants, and coarticulation with contiguous segments. Accordingly, the segmentation criteria for these phones included an additional inspection of abrupt changes and constriction of the waveform, attention to formant transitions from vowels segments, and the relative low onset frequency for F3 (Bradley and Willis, 2012; Kent and Read, 2001; Morgan and Sessarego, 2016). There were instances in which realizations with one occlusion and an approximant phase appeared in trill contexts. These instances were omitted from the analysis as only 
allophones that presented zero lingual closures were considered for this study. In total, 1,928 approximant tokens were selected for this analysis from a grand total of 5,182 phonemic samples, from which approximant tokens were collected. Table 2 shows the distribution of tokens per generational group and language variety.

Table 2. Distribution of approximant tokens and total phonemic realizations per age group and language variety. *Total phonemic realizations for Islander Creole are composed of approximant allophones and non-rhoticity that occurs in some postvocalic environments and in word-final contexts.

\begin{tabular}{|c|c|c|}
\hline Language Groups & Approximant Tokens & Total Phonemic Realizations \\
\hline *Islander Creole & 328 & 580 \\
\hline Raizal Spanish $-1^{\text {st }}$ Generation (R1) & 735 & 1450 \\
\hline Raizal Spanish $-2^{\text {nd }}$ Generation (R2) & 434 & 1446 \\
\hline Raizal Spanish $-3^{\text {rd }}$ Generation (R3) & 281 & 1449 \\
\hline Continental Spanish & 150 & 689 \\
\hline
\end{tabular}

A first glance at the distribution of approximant allophones between Raizal generations and the two contact languages (i.e., Islander Creole and Continental Spanish) show a decreasing trend of allophonic production in third generation Raizal Spanish speakers that approximates the rates in monolingual Spanish. Subsequently, a chi-square test using the chisq.test() function in $\mathrm{R}$ was conducted to determine a significant association between language group and the rhotic production (R Core Team, 2013). Results of the test revealed that rhotic production differ across the linguistic classification $\left(\chi^{2}=239.18, \mathrm{df}=4, \mathrm{p}\right.$-value $\left.=<2.2 \mathrm{e}-16\right)$, suggesting different rhotic realizations by language groups. This is a preliminary finding that suggest a generational change in rhotic articulation. This pattern is illustrated in Figure 4, which shows the overall proportion of approximant allophones collected from each generation of Raizal Spanish speakers.

Figure 4. Distribution of approximant rhotics in the varieties of the Archipelago. R1, R2, and R3 correspond to the first, second, and third generations of bilingual Spanish Raizales, respectively.

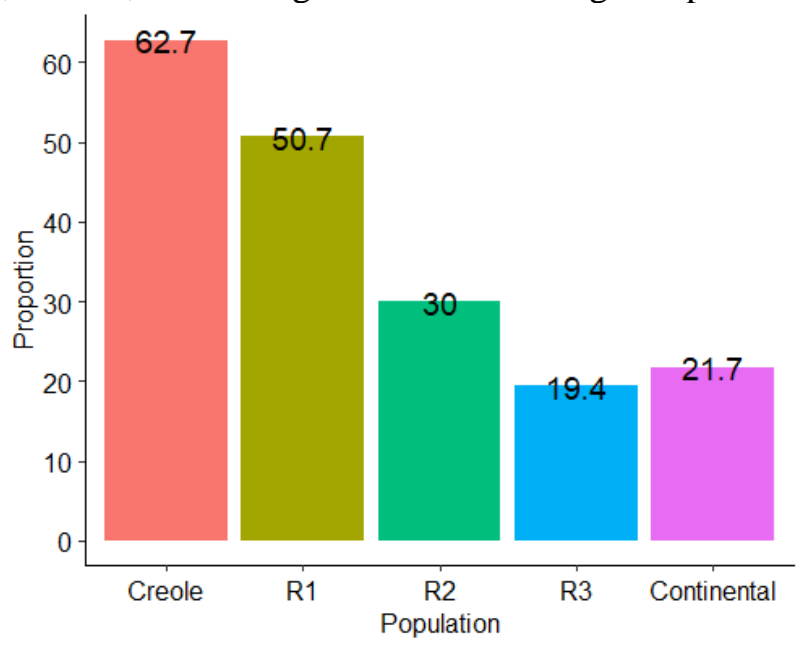

As seen in Figure 4, there seems to be an association between certain Raizal Spanish generations and either Islander Creole or Continental Spanish in terms of the proportions of occurrence of approximant rhotics. Rates of use in second generation 
appear in an intermediate position between first and third generation. Allophones for Islander Creole are composed of non-rhoticity and approximant realizations, including retroflex and bunched tongue tip articulations (Restrepo-Ramos, 2019). Figure 5 summarizes the occurrences of taps and trills in the bilingual Raizal Spanish in the two main islands of the Archipelago.

Figure 5. Distribution of zero-occlusion allophones in Raizal Spanish in both islands of the Archipelago: Old Providence and San Andres.

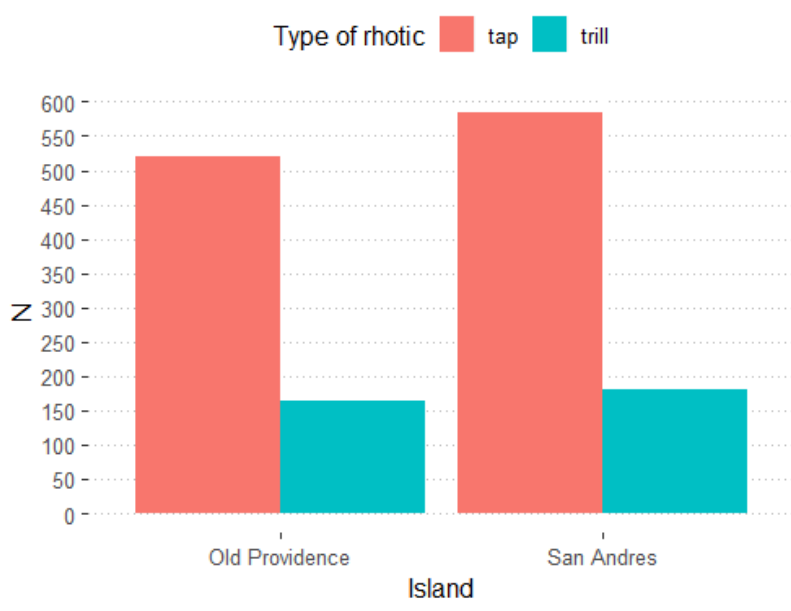

In general, approximant taps appear more frequently in both islands compared to approximant trills, mainly due to appearing in all word contexts, except in initial-word positions. When we compare the segmental duration of rhotics across generation of Raizal Spanish with the two contact varieties in Figure 6, a clear distinction between Spanish and Creole is observed, as approximant post-alveolar Creole rhotics are realized with longer durational cues.

Figure 6. A comparison of approximant rhotic duration values between varieties and across generations of Raizal Spanish.

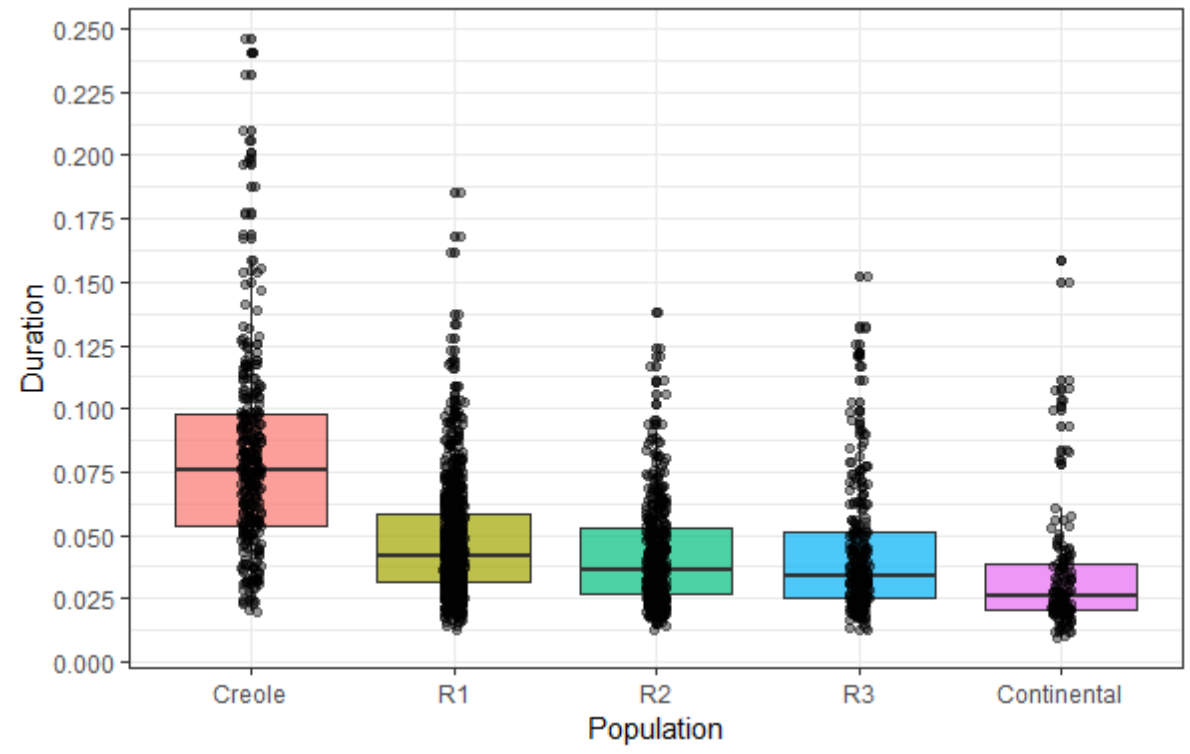


These differences seem to be language specific, since both bilingual and monolingual varieties of Spanish appear with similar duration values, as seen in Figure 6. This shows that Raizal Spanish and Continental Spanish produce shorter rhotic segments compared to Raizal Creole.

Figure 7. A comparison of approximant tap and trill duration between Spanish varieties and Raizal Creole.
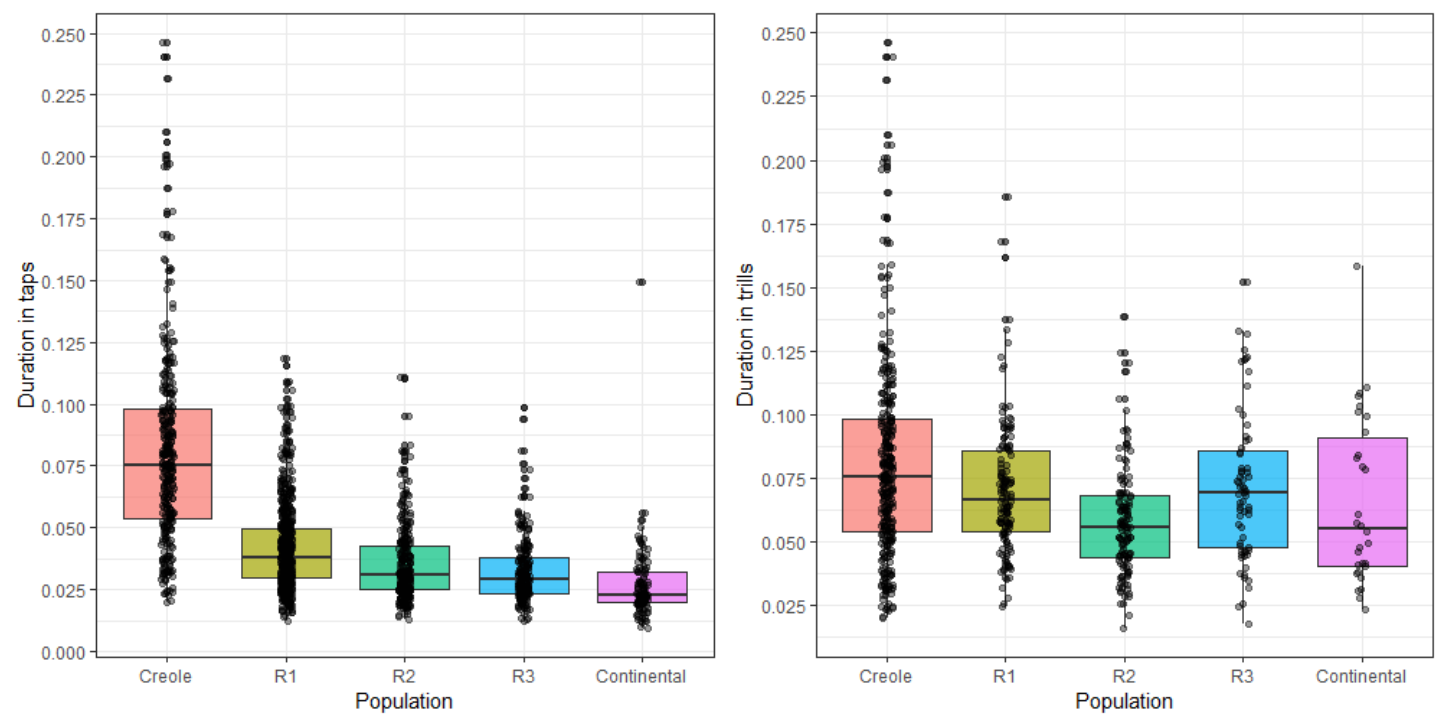

The differences between approximant taps and trills and Creole approximants are further detailed in Figure 7. Taps are clearly realized with shorter duration values, while trills appear longer than taps and closer to Creole rhotics. The fact that approximant trills are produced with longer durations than approximant taps signal a longer trill realization. Despite this, approximant rhotics in Islander Creole still appear with greater variation and with higher mean durations than the Spanish realization in both tap and trill allophones.

Finally, formant frequencies properties for each individual token in the form of F3 and F2 were extracted. The extraction of these resonances was done with the aim of comparing not only F3 measurements but also the distance between F3-F2. A Praat script was used to automatically extract the acoustic information of the labeled segments in the TextGrid (Kawahara, 2010). These measurements were saved on a spreadsheet and were further analyzed to determine the resonance properties of approximant rhotics produced across generations of Raizal Spanish compared to the languages in contact: Islander Creole and Continental Spanish. Outliers in the formant measurements that fell outside the 1.5 interquartile range $\left(1.5^{*} \mathrm{IQR}\right)$ were removed from the analysis to maintain the assumption of equal variance between linguistic groups (Tabachnick and Fidell 1996). Approximant variants have been reported with an extensive period of r-coloring into following vowels when no occlusion was produced (Bradley and Willis, 2012). The analysis of r-coloring is more appropriate for intervocalic taps and trills as these segments are surrounded by vowels. However, in this study, I examined all the approximant allophones regardless of the word context across generations of bilingual speakers and in the languages in contact. Thus, the analysis of r-coloring is outside the scope of this study. Formant frequency data was submitted to R for statistical analysis (R Core Team, 2013). The following section examines the potential change in progress in rhotic production across generations of bilingual speakers as measured by their formant frequencies. 


\section{Results}

This section starts with an overall comparison of the formant frequencies between generations of Raizal Spanish, and the languages in contact, Islander Creole, and Continental Spanish. Then, I will present the specific results for the acoustic properties of approximant allophones in the islands of the Archipelago: San Andres and Old Providence.

\subsection{Overall comparison between linguistic groups}

The first comparison involves the formant-lowering effect of $\mathrm{F} 3$ and the narrowing space of F3-F2 of rhotics across generations of bilingual Raizal Spanish. Figure 8 shows the crosslinguistic comparison of formant frequencies between linguistic groups.

Figure 8. A comparison of F3 and F3-F2 frequencies between generations of Raizal Spanish, Continental Spanish, and Islander Creole.
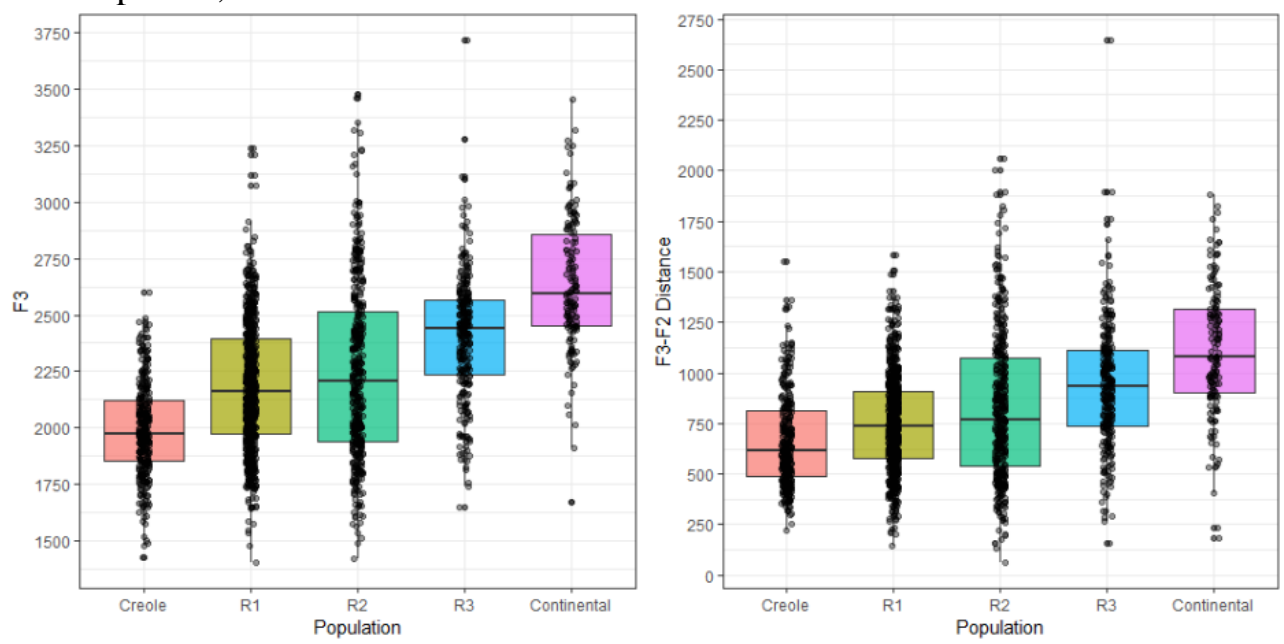

Accordingly, when we visualize the mean formant frequencies in these population groups in Figure 8, both formant measurements follow the same increasing trend between generations toward Continental Spanish, suggesting differences between older and younger Raizales. While third generation approaches the values encountered in Continental Spanish, the older first generation resembles more Islander Creole formants. In order to visualize further these differences and similarities, rhotics in these population groups were divided in terms of F3 and the F3-F2 spacing realized independently between taps and trills. Figure 9 shows the relationship between F3, and the formant measurements found in the distance between F3 and F2 in all groups. 
Figure 9. A comparison of F3 and F3-F2 frequencies in approximant taps and trills between Spanish varieties and Islander Creole (left for taps and right for trills).
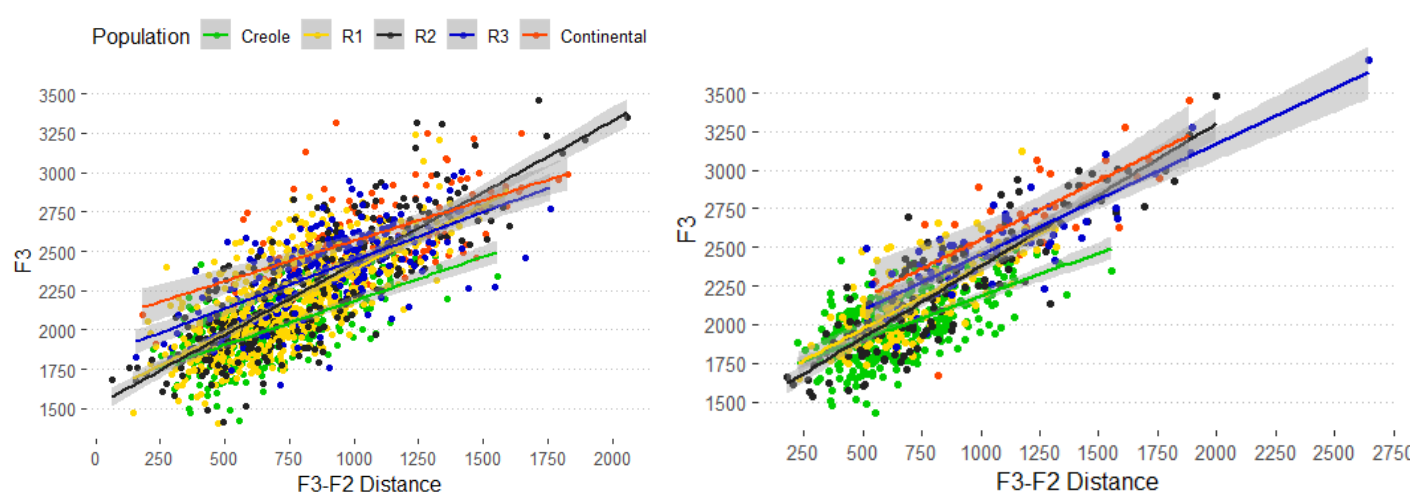

Positive correlation lines seen in Figure 9 indicate that there is a linear relationship in F3 frequencies and F3-F2 distance in trills (Pearson $\mathrm{r}(700)=.82, \mathrm{p}=<2.2 \mathrm{e}-16$ ) and taps (Pearson $\mathrm{r}(1552)=.75, \mathrm{p}=<2.2 \mathrm{e}-16)$ between all population groups. Likewise, it can be observed that Continental Spanish and Islander Creole present regression lines that lie on two opposite sides of the plot, while generations of Islander Creole gravitate between both languages. In addition, it is worth noting that, in general terms, third generation seem to approach Continental Spanish, while first and second generation present lower F3 values, and thus, smaller F3-F2 spacing.

Whether these observations corroborate statistical differences between a Raizal generation with Islander Creole is tested with two linear mixed effects models for approximant taps and trills. Our null hypothesis states that there are no significant differences between older generations of Raizal Spanish and Islander Creole in terms of F3 and F3-F2 distance frequencies of approximant trills and taps. Precisely, failing to reject the null hypothesis in any of the following analysis will indicate that no statistically significant differences exist between Creole approximants and approximant trills/taps in senior Raizales, and thus, this will suggest generational transfer of phonological features in Raizal bilinguals. Table 3 shows the results for the F3 comparison ${ }^{3}$.

\footnotetext{
3 The intercept consists of Islander Creole measurements for all the statistical tests in these analyses.
} 
Table 3. Linear, mixed effects models of F3 between Islander Creole approximants and Spanish tap (left) and trill (right) approximants in generations of Raizal Spanish informants and Continental Spanish.

\begin{tabular}{|c|c|}
\hline $\begin{array}{c}\text { Random Variables } \\
\text { Token and Informant }\end{array}$ & $\begin{array}{c}\text { Dependent variable: } \\
\text { F3 in Taps }\end{array}$ \\
\hline $\begin{array}{c}\text { Raizal - First } \\
\text { Generation }\end{array}$ & $\begin{array}{c}\text { Estimate: } 213.27 \\
(\mathrm{p}=0.0102)^{*}\end{array}$ \\
\hline $\begin{array}{c}\text { Raizal - Second } \\
\text { Generation }\end{array}$ & $\begin{array}{c}\text { Estimate: } 278.31 \\
(\mathrm{p}=0.0014)^{* *}\end{array}$ \\
\hline $\begin{array}{c}\text { Raizal - Third } \\
\text { Generation }\end{array}$ & $\begin{array}{c}\text { Estimate: } 368.63 \\
(\mathrm{p}=4.91 \mathrm{e}-05)^{* * *}\end{array}$ \\
\hline Continental Spanish & $\begin{array}{c}\text { Estimate: } 595.41 \\
(\mathrm{p}=4.91 \mathrm{e}-05)^{* * *}\end{array}$ \\
\hline Intercept & Estimate: $2,010.19$ \\
\hline Observations & 1,554 \\
\hline Log Likelihood & $-10,828.06$ \\
\hline Akaike Inf. Crit. & $21,672.13$ \\
\hline Bayesian Inf. Crit. & $21,714.91$ \\
\hline Note: ${ }^{*} \mathrm{p}<0.05$ & ${ }^{* *} \mathrm{p}<0.01$ \\
\hline
\end{tabular}

\begin{tabular}{|c|c|}
\hline $\begin{array}{c}\text { Random Variables } \\
\text { Token and Informant }\end{array}$ & $\begin{array}{c}\text { Dependent variable: } \\
\text { F3 in Trills }\end{array}$ \\
\hline $\begin{array}{c}\text { Raizal - First } \\
\text { Generation }\end{array}$ & $\begin{array}{c}\text { Estimate: } 201.39 \\
(p=\mathbf{0 . 0 6 2 8 5})\end{array}$ \\
\hline $\begin{array}{c}\text { Raizal - Second } \\
\text { Generation }\end{array}$ & $\begin{array}{c}\text { Estimate: } 382.60 \\
(p=0.00136)\end{array}$ \\
\hline $\begin{array}{c}\text { Raizal - Third } \\
\text { Generation }\end{array}$ & $\begin{array}{c}\text { Estimate: } 500.91 \\
(p=4.34 \mathrm{e}-05)^{* * *}\end{array}$ \\
\hline Continental Spanish & $\begin{array}{c}\text { Estimate: } 688.50 \\
(p=4.41 \mathrm{e}-06)\end{array}$ \\
\hline Intercept & $2,009.12$ \\
\hline Observations & 702 \\
\hline Log Likelihood & $-4,834.83$ \\
\hline Akaike Inf. Crit. & $9,685.66$ \\
\hline Bayesian Inf. Crit. & $9,722.09$ \\
\hline Note: ${ }^{*} \mathrm{p}<0.05$ & ${ }^{* *} \mathrm{p}<0.01 \quad{ }^{* * *} \mathrm{p}<0.001$ \\
\hline
\end{tabular}

Results for taps in the left side of Table 3 shows that all F3 values reach statistical significance at $\mathrm{p}<0.05$, and thus, approximant taps in Continental Spanish and Raizal Spanish significantly differ from Islander Creole approximants. However, the estimates of younger Raizales seem to increasingly converge towards Continental Spanish, while taps in senior informants present lower F3 values that approach those of Islander Creole. Similarly, results displayed for trills show the same pattern, where formant values in younger generations are diverging toward Continental Spanish. On the contrary, trills in first generation present values that fall barely outside the significance threshold, as this is the only age group that shows no statistical difference in terms of F3 frequencies with Islander Creole. Although the differences in F3 approaches a significance level ( $p=$ 0.06285 ) and the estimate with Islander Creole is still distant (at $201.39 \mathrm{~Hz}$ ), it appears that trills in this generation are realized with a different articulatory configuration. While a lowered F3 typically characterizes an English/Creole-like rhotic, it has shown here and elsewhere that the decreasing values of this resonance often approaches F2 (Zhou et al, 2008; Lehiste, 1964; Espy-Wilson, 1992). Precisely, the same test for significance was conducted in tap and trills and F3-F2 distance. Results are summarized in Table 4. 
Table 4. Linear, mixed effects models of the distance between F3-F2 between Islander Creole approximants and Spanish tap (left) and trill (right) approximants in generations of Raizal Spanish and Continental Spanish.

\begin{tabular}{|c|c|c|c|}
\hline $\begin{array}{l}\text { Random Variables } \\
\text { Token and Informant }\end{array}$ & $\begin{array}{c}\text { Dependent variable: } \\
\text { F3-F2 Distance in } \\
\text { Taps }\end{array}$ & $\begin{array}{l}\text { Random Variables } \\
\text { Token and Informant }\end{array}$ & $\begin{array}{c}\text { Dependent variable: } \\
\text { F3-F2 Distance in } \\
\text { Trills }\end{array}$ \\
\hline $\begin{array}{c}\text { Raizal - First } \\
\text { Generation }\end{array}$ & $\begin{array}{c}\text { Estimate: } 72.22 \\
(p=\mathbf{0 . 3 6 2 1 3 0})\end{array}$ & $\begin{array}{l}\text { Raizal - First } \\
\text { Generation }\end{array}$ & $\begin{array}{c}\text { Estimate: } 72.69 \\
(p=\mathbf{0 . 4 9 9 5 5 3})\end{array}$ \\
\hline $\begin{array}{c}\text { Raizal - Second } \\
\text { Generation }\end{array}$ & $\begin{array}{l}\text { Estimate: } 132.56 \\
(p=\mathbf{0 . 1 0 7 4 5 6})\end{array}$ & $\begin{array}{c}\text { Raizal - Second } \\
\text { Generation }\end{array}$ & $\begin{array}{l}\text { Estimate: } 255.85 \\
(p=0.028260)^{*}\end{array}$ \\
\hline $\begin{array}{c}\text { Raizal - Third } \\
\text { Generation }\end{array}$ & $\begin{array}{l}\text { Estimate: } 185.32 \\
(p=0.026419)^{*}\end{array}$ & $\begin{array}{c}\text { Raizal - Third } \\
\text { Generation }\end{array}$ & $\begin{array}{l}\text { Estimate: } 379.97 \\
(p=0.001614)^{* * *}\end{array}$ \\
\hline Continental Spanish & $\begin{array}{l}\text { Estimate: } 399.01 \\
(p=0.000135)^{* * *}\end{array}$ & Continental Spanish & $\begin{array}{l}\text { Estimate: } 557.55 \\
(p=0.000164)^{* * *}\end{array}$ \\
\hline Intercept & Estimate: 695.14 & Intercept & Estimate: 696.91 \\
\hline Observations & 1,554 & Observations & 702 \\
\hline Log Likelihood & $-10,791.52$ & Log Likelihood & $-4,852.91$ \\
\hline Akaike Inf. Crit. & $21,599.04$ & Akaike Inf. Crit. & $9,721.81$ \\
\hline Bayesian Inf. Crit. & $21,641.83$ & Bayesian Inf. Crit. & $9,758.24$ \\
\hline Note: ${ }^{*} \mathrm{p}<0.0{ }^{* *} \mathrm{p}$ & ${ }^{* * *} \mathrm{p}<0.001$ & \multicolumn{2}{|c|}{ Note: ${ }^{*} \mathrm{p}<0.05 \quad{ }^{* *} \mathrm{p}<0.01$} \\
\hline
\end{tabular}

Results in Table 4 indicate that the F3-F2 distance in approximant taps and trills is statistically significant in third generation and Continental Spanish, which suggest that this formant spacing in the youngest Raizales bear less resemblance to Islander Creole approximants. The key piece of evidence comes from older generation of bilingual Raizales, in which no significant differences were found with Creole approximants in the F3-F2 spacing, and thus, they seem to be approaching the frequencies of a Creole-like rhotic rather than an alveolar Spanish approximant realization. As such, not only the lack of effect is seen in taps produced by senior $(\mathrm{p}=0.362130)$ and second generation Raizales $(\mathrm{p}=0.107456)$, but it is less prevalent in trills only in first generation $(\mathrm{p}=0.499553)$. Furthermore, Continental Spanish displays the opposite pattern, as these rhotics are further dissociated with Creole approximants, suggesting that the properties of Raizal Spanish rhotics change across age groups. The fact that first generation Raizales in both taps and trills were not significant predictors in the model due to the high $\mathrm{p}$-value ( $\mathrm{p}=$ 0.362130 for taps and $p=0.499553$ for trills) indicate that the variation patterns are derived from the transfer of phonological features from the Creole language and dependent upon generational differences. These findings confirm the hypotheses posited in this study, as there are generational differences in rhotic production that are converging towards the languages in contact in the Archipelago.

\subsection{Comparison between linguistic groups in the islands of the Archipelago}

A second and final point of interest consists of determining whether these patterns depart from a Creole variety in either San Andres or Old Providence. As the previous results have shown, the variation in the form of F3 and F3-F2 frequencies across generations of Raizales is not random, but rather these are correlated with one of the two varieties in contact. For the last part of this section, I have divided the analysis according to the measurements for F3-F2 distance in both islands of the Archipelago: San Andres and Old Providence. This is done because F3-F2 differences are shown to be statistically significant in both approximant taps and trills as demonstrated in the previous analysis. 
Again, this is statistically tested with linear mixed effects models for taps and trills produced by informants in San Andres and Old Providence. Results for the differences in F3-F2 distance in approximant taps are summarized in Table 5.

Table 5. Linear, mixed effects models of F3-F2 distance frequencies between Islander Creole approximants and Spanish approximant taps in generations of Raizal Spanish informants and Continental Spanish in Old Providence (OP) and San Andres (SAI).

\begin{tabular}{|c|c|}
\hline $\begin{array}{l}\text { Random Variables } \\
\text { Token and Informant }\end{array}$ & $\begin{array}{c}\text { Dependent variable: } \\
F 3-F 2 \text { in } S A I\end{array}$ \\
\hline $\begin{array}{c}\text { Raizal - First } \\
\text { Generation }\end{array}$ & $\begin{array}{l}\text { Estimate: } 63.61 \\
(p=\mathbf{0 . 4 5 2 6 7 7})\end{array}$ \\
\hline $\begin{array}{c}\text { Raizal - Second } \\
\text { Generation }\end{array}$ & $\begin{array}{c}\text { Estimate: } 144.91 \\
(p=\mathbf{0 . 1 0 9 4 2 4})\end{array}$ \\
\hline $\begin{array}{l}\text { Raizal - Third } \\
\text { Generation }\end{array}$ & $\begin{array}{l}\text { Estimate: } 81.95 \\
(p=\mathbf{0 . 3 5 3 2 4 3})\end{array}$ \\
\hline Continental Spanish & $\begin{array}{l}\text { Estimate: } 402.88 \\
(p=0.000171)^{* * *}\end{array}$ \\
\hline Intercept & 693.41 \\
\hline Observations & 1,033 \\
\hline Log Likelihood & $-7,126.87$ \\
\hline Akaike Inf. Crit. & $14,269.73$ \\
\hline Bayesian Inf. Crit. & $14,309.25$ \\
\hline Note: $\quad{ }^{*} \mathrm{p}<0.05{ }^{* * *}$ & ${ }^{* * *} \mathrm{p}<0.001$ \\
\hline
\end{tabular}

\begin{tabular}{|c|c|}
\hline $\begin{array}{c}\text { Random Variables } \\
\text { Token and Informant }\end{array}$ & $\begin{array}{c}\text { Dependent variable: } \\
\text { F3-F2 in OP }\end{array}$ \\
\hline $\begin{array}{c}\text { Raizal - First } \\
\text { Generation }\end{array}$ & $\begin{array}{c}\text { Estimate: } 68.50 \\
(\mathrm{p}=\mathbf{0 . 4 5 8 5 4})\end{array}$ \\
\hline $\begin{array}{c}\text { Raizal - Second } \\
\text { Generation } \\
\text { Raizal - Third } \\
\text { Generation }\end{array}$ & $\begin{array}{c}\text { Estimate: } 104.26 \\
(\mathrm{p}=\mathbf{0 . 2 7 9 2 6})\end{array}$ \\
\hline $\begin{array}{c}\text { Estimate: } 277.93 \\
(\mathrm{p}=0.00692)^{* *}\end{array}$ \\
\hline Continental Spanish & $\begin{array}{c}\text { Estimate: } 380.29 \\
(\mathrm{p}=0.00053)^{* * *}\end{array}$ \\
\hline Intercept & 709.81 \\
\hline Observations & 1,308 \\
\hline Log Likelihood & $-8,970.41$ \\
\hline Akaike Inf. Crit. & $17,956.83$ \\
\hline Bayesian Inf. Crit. & $17,998.24$ \\
\hline Note: ${ }^{*} \mathrm{p}<0.05{ }^{* *} \mathrm{p}<0.01{ }^{* * *} \mathrm{p}<0.001$ \\
\hline
\end{tabular}

Indeed, no significant differences were found in first and second generation Raizales in both islands. However, not only the same insignificant effect was found in older generations but also in younger Raizales in San Andres. This unexpected result might challenge our assumption that older generations are producing a tap that is realized with an increasingly different point of articulation that approximates Creole rhotics. An inspection of the overall F3 formant values in taps in San Andres indicates that third generation present the highest F3 mean frequency across all generations $(2378 \mathrm{~Hz})$. Likewise, front vowels make up 33\% ( $\mathrm{N}=141 / 421)$ of the preceding segments and $31 \%$ $(\mathrm{N}=131 / 421)$ of following segments of the tap's dataset in third generation. Back vowels only accounts for $15 \%(\mathrm{~N}=65 / 421)$ and $17 \%(\mathrm{~N}=74 / 421)$ of preceding and following segments, respectively. This suggest that F2 in third generation is reflecting the high proportion of front vowels that surround taps. These results indicate that F2 might be increasing rather than having the case where F3 is lowering, and thus, the tongue gesture is still realized reflecting an alveolar point of articulation.

In a similar manner, two mixed effects tests were conducted to determine the relationship between the mean F3-F2 values in Islander Creole approximants and bilingual and monolingual Spanish approximant trills. Results are summarized in Table 6. 
Table 6. Linear, mixed effects models of F3-F2 distance frequencies between Islander Creole approximants and Spanish approximant trills in generations of Raizal Spanish informants and Continental Spanish in Old Providence (OP) and San Andres (SAI).

\begin{tabular}{|c|c|}
\hline $\begin{array}{c}\text { Random Variables } \\
\text { Token and Informant }\end{array}$ & $\begin{array}{c}\text { Dependent variable } \\
\text { F3-F2 in SAI }\end{array}$ \\
\hline $\begin{array}{c}\text { Raizal - First } \\
\text { Generation }\end{array}$ & $\begin{array}{c}\text { Estimate: } 37.75 \\
(\mathrm{p}=\mathbf{0 . 6 4 3 6 4})\end{array}$ \\
\hline $\begin{array}{c}\text { Raizal }- \text { Second } \\
\text { Generation }\end{array}$ & $\begin{array}{c}\text { Estimate: } 263.42 \\
(\mathrm{p}=0.00721)^{* *}\end{array}$ \\
\hline $\begin{array}{c}\text { Raizal }- \text { Third } \\
\text { Generation }\end{array}$ & $\begin{array}{c}\text { Estimate: } 205.09 \\
(\mathrm{p}=0.03417)^{*}\end{array}$ \\
\hline Continental Spanish & $\begin{array}{c}\text { Estimate: } 537.21 \\
(\mathrm{p}=7.40 \mathrm{e}-06)^{* * *}\end{array}$ \\
\hline Intercept & Estimate: 695.13 \\
\hline Observations & 539 \\
\hline Log Likelihood & $-3,687.50$ \\
\hline Akaike Inf. Crit. & $7,390.99$ \\
\hline Bayesian Inf. Crit. & $7,425.31$ \\
\hline Note: ${ }^{*} \mathrm{p}<0.05$ & $* * * \mathrm{p}<0.01$ \\
\hline
\end{tabular}

\begin{tabular}{|c|c|}
\hline $\begin{array}{c}\text { Random Variables } \\
\text { Token and Informant }\end{array}$ & $\begin{array}{c}\text { Dependent variable: } \\
\text { F3-F2 in OP }\end{array}$ \\
\hline $\begin{array}{c}\text { Raizal - First } \\
\text { Generation }\end{array}$ & $\begin{array}{c}\text { Estimate: } 81.17 \\
(p=\mathbf{0 . 5 5 3 6 0 9})\end{array}$ \\
\hline $\begin{array}{c}\text { Raizal - Second } \\
\text { Generation }\end{array}$ & $\begin{array}{c}\text { Estimate: } 197.23 \\
(p=\mathbf{0 . 1 8 8 4 8 5})\end{array}$ \\
\hline $\begin{array}{c}\text { Raizal - Third } \\
\text { Generation }\end{array}$ & $\begin{array}{c}\text { Estimate: } 525.32 \\
(p=0.001219)^{* *}\end{array}$ \\
\hline Continental Spanish & $\begin{array}{c}\text { Estimate: } 589.80 \\
(p=0.000466)^{* * *}\end{array}$ \\
\hline Intercept & Estimate: 701.74 \\
\hline Observations & 853 \\
\hline Log Likelihood & $-5,760.56$ \\
\hline Akaike Inf. Crit. & $11,537.13$ \\
\hline Bayesian Inf. Crit. & $11,575.12$ \\
\hline Note: ${ }^{*} \mathrm{p}<0.05{ }^{* *} \mathrm{p}<0.01{ }^{* * *} \mathrm{p}<0.001$ \\
\hline
\end{tabular}

This final analysis demonstrates that the F3-F2 distance in trills in third generation and Continental Spanish are significantly different to Islander Creole rhotics. On the contrary, these formant frequencies in first generation Raizales failed to reach a significant effect with high p-values, suggesting a null effect and non-significant differences between senior trills and Creole approximants. This null effect is displayed in both islands and include second generation to a lesser degree in Old Providence only $(\mathrm{p}=$ 0.188). These results will be discussed in detail in the following section.

\section{Discussion and Conclusion}

This work has presented a comparative examination of zero-occlusion rhotic production across generations of Raizal Spanish in the Archipelago of San Andres. In doing so, I examined the acoustic correlates in the form of formant frequencies that characterize approximant rhotics in the languages under study to test the potential correlation between generations of Raizal Spanish and either Islander Creole or Continental Spanish. Correspondingly, approximant Spanish taps and trills were compared in terms of these formant measurements with Raizal Creole and it was found that F3 frequencies in trills in senior generations barely approximated the statistically significant threshold at $\mathrm{p}<$ 0.05 . While these results show that significant differences in terms of F3 frequencies with Raizal Creole vary across generations of Raizales, they also show that younger generations presented similar p-values with Continental Spanish. This, in turn, greatly diverged from senior informants. However, the greatest non-significant effect was found when the distance of F3-F2 was contrasted in approximant taps and trills between generations of Raizal Spanish and Raizal Creole in both islands of the Archipelago. Approximant taps in both islands failed to reach statistical differences with Islander Creole between almost all generations, which challenged the assumption that only approximant taps in older generations are approaching the F3-F2 distance frequencies of 
Islander Creole. While it is possible that, in fact, taps failed to reach statistical significance regardless of the generations of Raizal Spanish, it seems the case that F2 is increasing rather than F3 decreasing in younger generations due to the high proportion of front vowels that surround taps in the dataset for third generation. On the contrary, trills showed more straightforward differences between older/younger informants, since it seems that this variant is increasingly showing non-statistically significant differences in older generations of Old Providence informants at $p$-values that exceed $p>0.50$. For instance, the intermediate second generation exhibits non-significant differences much lower than first generation ( $\mathrm{p}=0.18$ and $\mathrm{p}=0.55$, respectively). While this generational effect is not present in San Andres, significant differences in F3-F2 distance frequencies in senior Raizales are virtually non-existent with $\mathrm{p}$-values of $\mathrm{p}=0.64$ ).

All these findings have shown that formant frequencies in taps and trills across generations of Raizales are associated with either Raizal Creole or Continental Spanish. This result suggests that both taps and trills in older generations appear to be realized with a place of articulation that increasingly converges in the direction of Creole approximants. Likewise, the contrary can also be said about younger generations producing bilingual Spanish rhotics, as these formants are diverging from the senior standard and converging in the direction of Continental Spanish alveolar approximants. With these results on the generational differences of formant frequencies, the evidence suggests that there is a change in progress in the form of the place of articulation of Raizal Spanish approximants. The comparison of non-significant $p$-values makes a clear case for the association of a generation of Raizal Spanish with one of the languages in contact, which directly answers the last part of the first research question posited for this study on the change in progress and the subsequent convergence of a generation with either Raizal Creole or Continental Spanish. Finally, there are mixed results in terms of which island is leading a generational change: San Andres is leading the change in terms of a gradual shift of F3-F2 distance in trills for both second and third generation; and Old Providence presents a first generational change of the F3-F2 distance in taps for third generation only. An additional examination of preceding and following context could have offered further insights into the articulation of these rhotics across all linguistic varieties. Thus, the effect of word context that includes vowels, consonants, and pausal contexts should be examined in future research.

The ongoing change of approximant rhotics of the Archipelago resonates with the framework discussed on contact situations where a Creole language is in direct contact with a national non-lexifier language (Snow, 2000; Aceto, 1999). If we apply the explanation of a Creole continua to the processes of change in this bilingual variety in a contact scenario, we would have to attribute any potential linguistic influence on the languages in contact. In this study, the case of zero-occlusion rhotics presents evidence against a Creole-like continuum of Raizal Spanish rhotics, as these segments do not present gradual changes or steady behavior in the direction of Raizal Creole, but rather are becoming more similar to the national non-lexifier language in contact. If the concept of decreolization implies a Creole continuum in which only a Creole basilect and the lexifier acrolect exist in the two extremes of the spectrum, then clearly there is a different situation reflected in the production of Raizal Spanish rhotics, which suggest an influence in some nature by the existence of the non-lexifier language. First, approximant rhotics in younger generations are converging toward Continental Spanish, and thus, diverging from the English-like acrolect. Secondly, these findings suggest that transfer of phonetic features from the source language to the recipient bilingual Spanish is in place, which 
seems to indicate that the change has been partially produced due to the influence of the languages in contact. However, it has been documented dialectal variation of Spanish rhotics in monolingual varieties that differ from the apico-alveolar trill variants. For instance, several studies have identified a post-alveolar approximant rhotic in place of an apico-alveolar trill in Costa Rican Spanish (Lipski, 2011), an assibilated variant in Central Valley Costa Rican Spanish (Adams, 2002) and in Highland Ecuadorian Spanish (Bradley, 1999), and a velarized production in Puerto Rican Spanish (Campos-Astorkiza, 2012). The phenomenon of rhotic variation is not exclusive to monolingual scenarios. Retroflex approximants have been reported in bilingual varieties of Spanish in direct contact with English-based Creoles (Balam, 2012; Zimmer, 2011), coexisting with US English (Ramos-Pellicia, 2007), and with indigenous languages in the Yucatan peninsula (Lope-Blanch, 1975).

Instead of the prevalence of an innovative variant, the bilingual approximant rhotics of the Archipelago of San Andres presents a generational change toward a normative alveolar monolingual approximant. The process is accelerated among second and third generation Raizales who seem to be more balanced bilinguals educated in the Spanish-only education system of the islands and Continental Colombia. The apparent rhotic changes in monolingual and bilingual varieties toward an assibilated (Adams, 2002) or a backed innovative variant (Campos-Astorkiza, 2012; Balam, 2013; Zimmer, 2011; Lipski, 2011; Ramos-Pellicia, 2007; Bradley, 1999; Lope-Blanch, 1975) is reversed in Raizal Spanish and accelerated among second and third generation speakers due to stable bilingualism and the pressure to produce an apico-alveolar approximant as close as possible to that of the prestigious Spanish norm.

In sum, this paper has presented an analysis on the ongoing sound change in bilingual rhotics in the communities of this Caribbean archipelago. It is my intention that these results foster more work on other sound variants in this bilingual community and shed more light on the effects of contact with the national language of Spanish in this part of the Caribbean.

\section{References}

Aceto, M. 1999. Looking beyond decreolization as an explanatory model of language change in Creole-speaking communities. JPCL, 14(1), 93-119. https://doi.org/10.1075/jpcl.14.1.04ace

Adams, C. 2002. Strong assibilation and prestige: A sociolinguistic study in the Central Valley of Costa Rica. Ph.D. Dissertation, University of California.

Restrepo-Ramos, F. 2021. Non-vibrant bilingual rhotics in a Creole-Spanish Contact Scenario. IULC Working Papers, 21(1).

Restrepo-Ramos, F. 2019. A sociophonetic analysis of Islander Creole rhotics. Proceedings of the Florida Linguistics Yearly Meeting, 6(1), pp. 76-90.

Balam, O. 2013. Neutralization of the intervocalic rhotic contrast in Northern Belizean Spanish. Borealis-An International Journal of Hispanic Linguistics, 2(2), 285315. https://doi.org/10.7557/1.2.2.2601 
Bartens, A. 2013. San Andres Creole English. The Survey of Pidgin and Creole Languages, 1, 101-114.

Bartens, A. 2002. Another short note on creoles in contact with non-lexifier prestige languages. Lingua Americana, 6(10), 117.

Blecua, B. 2008. Los sonidos vibrantes: aspectos comunes y variación. In New trends in experimental phonetics: selected papers from the IVth International Conference on Experimental Phonetics:(Granada, 11-14 feb. 2008), pp. 23-30. Universidad de Granada.

Blecua, B. 2001. Las vibrantes del español: manifestaciones acústicas y procesos fonéticos. Universitat Autònoma de Barcelona.

Boersma, P., \& Weenink, D. 2018. Praat: doing phonetics by computer (Version 6.0.40) [Computer program]. Retrieved May, 2018.

Bradley, T. G., \& Willis, E. W. 2012. Rhotic variation and contrast in Veracruz Mexican Spanish. Estudios de fonética experimental, 21, 43-74.

Bradley, T. G. 2006. Spanish rhotics and Dominican hypercorrect/s. Probus, 18(1), 133. https://doi.org/10.1515/PROBUS.2006.001

Bradley, T. G. 1999. Assibilation in Ecuadorian Spanish. In Formal Perspectives on Romance Linguistics. Selected Papers from the 28th Linguistics Symposium on Romance Languages. Amsterdam, John Benjamins Publishing Company (pp. 57-71).

Campos-Astorkiza, R. 2012. The phonemes of Spanish. In The Handbook of Hispanic Linguistics, 69, 89. Wiley and Sons.

Colantoni, L. 2006. Increasing periodicity to reduce similarity: an acoustic account of deassibilation in rhotics. In Selected proceedings of the 2nd Conference on Laboratory Approaches to Spanish Phonetics and Phonology (pp. 22-34). Somerville, MA: Cascadilla Proceedings Project.

Dittmann, M. 1992. El criollo sanandresano: Lengua y cultura. Cali: Universidad del Valle.

DANE - The National Administrative Department of Stastistics. 2005. 2005 Census of Colombia. [Online] Accessed on October 2017. Available on the Web: http://systema59.dane.gov.co/cgibin/RpWebEngine.exe/PortalAction?\&MODE $=$ MAIN\&BASE $=$ CG2005BASICO\&MAIN=WebServerMain.inl

Díaz-Campos, M. 2008. Variable production of the trill in spontaneous speech: Sociolinguistic implications. In Selected proceedings of the 3rd Conference on Laboratory Approaches to Spanish Phonology (pp. 47-58). 
Enciso-Patiño, P. 2004. Estado del arte de la etnoeducación en Colombia con énfasis en política pública. Colombia. Ministerio de Educación Nacional.

Espy-Wilson, C. Y. 1992. Acoustic measures for linguistic features distinguishing the semivowels/wjrl/in American English. The Journal of the Acoustical Society of America, 92(2), 736-757. https://doi.org/10.1121/1.403998

Florez, S. 2006. A Study of language attitudes in two Creole-speaking islands: San Andres and Providence (Colombia). Ikala, Revista de lenguaje y cultura, 11(17) pp.119-147.

Hagiwara, R. E. 1995. Acoustic realizations of American /r/ as produced by women and men. UCLA Working Papers in Phonetics No. 90. Los Angeles, CA: University of California.

Hammond, R. 1999. On the non-occurrence of the phone [r)] in the Spanish sound system. Advances in Hispanic Linguistics, ed. by Javier Gutiérrez-Rexach and Fernando Martínez-Gil, 135-151. Somerville, MA: Cascadilla Press.

Henriksen, N. 2015. Acoustic analysis of the rhotic contrast in Chicagoland Spanish: An intergenerational study. Linguistic Approaches to Bilingualism, 5(3), 285-321.

https://doi.org/10.1075/lab.5.3.01hen

Hualde, J. I. 2005. The sounds of Spanish. Cambridge: Cambridge University Press.

Johnson, K. 2011. Acoustic and Auditory Phonetics. Wiley-Blackwell, $3^{\text {rd }}$ Edition.

Kent, R. D., Read, C. (2001). The acoustic analysis of speech. Cengage Learning, 2nd Edition.

Klee C. \& Lynch A. 2009. Capítulo 1: Introducción. El español en contacto con otras lenguas. Georgetown University Press. P. 1-24.

Lehiste, I. 1964. Acoustical characteristics of selected English consonants. Research Center in Anthropology. Folklore and Linguistics, Indiana University, Bloomington.

Lipski, J. 2011. Socio-phonological variation in Latin American Spanish. The Handbook of Hispanic Sociolinguistics, 72-97.

Lope Blanch, J. M. 1975. Un caso de posible influencia maya en el español mexicano. Nueva Revista de Filología Hispánica, 24, 89-100.

Mayer, M. 1969. Frog, where are you? New York: Dial Press.

Melero-García, F., \& Cisneros, A. 2020. No es tan simple como parece. Current Theoretical and Applied Perspectives on Hispanic and Lusophone Linguistics, 27, 295. https://doi.org/10.1075/ihll.27.14mel 
Morgan, T. A., \& Sessarego, S. (2016). A phonetic analysis of intervocalic/r/in Highland Bolivian Spanish. Spanish in Context, 13(2), 195-211. https://doi.org/10.1075/sic.13.2.02mor

Morren R. 2001. Creole-based trilingual education in the Caribbean archipelago of San Andres, Providence and Santa Catalina. Journal of Multilingual and Multicultural Development, 22(3), 227-241. https://doi.org/10.1080/01434630108666434

Moya-Chaves, D. S. 2014. La situación sociolingüística de la lengua Creole de San Andrés Isla: el caso de San Luis. Colombian Applied Linguistics Journal, 16(1), 55-66. http://dx.doi.org/10.14483/udistrital.jour.calj.2014.1.a05

Navarro-Tomás, T. 1999. Manual de pronunciación española. Madrid: Consejo Superior de Investigaciones Científicas.

Ramos-Pellicia, M. F. 2007. Lorain Puerto Rican Spanish and 'r' in Three Generations, in J. Holmquist, A. Lorenzino \& L. Sayahi (eds.), Selected Proceedings of the Third Workshop on Spanish Sociolinguistics. Somerville, MA, Cascadilla Proceedings Project, pp. 53-60.

R Core Team. 2013. R: A language and environment for statistical computing. $\mathrm{R}$ Foundation for Statistical Computing, Vienna, Austria. URL http://www.Rproject.org/.

Snow, P. 2000. Caribbean Creole/non-lexifier contact situations: A provisional survey. Journal of Pidgin and Creole languages, 15(2), 339-343.

https://doi.org/10.1075/jpcl.15.2.06sno

Tabachnick, B. G., \& Fidell, L. S. 1996. Using multivariate statistics. 3rd edition. NY: Harper Collins.

Thomason, S. G. 2001. Language contact: An introduction. Georgetown University Press.

Willis, E. W. 2006. Trill variation in Dominican Spanish: An acoustic examination and comparative analysis. In Selected proceedings of the 9th Hispanic Linguistics Symposium (Vol. 1, pp. 121-131). Somerville, MA: Cascadilla Proceedings Project.

Winford, D. 2003. An introduction to contact linguistics. Malden, MA: Blackwell Pub.

Zahler, S., \& Daidone, D. 2014. A variationist account of trill/r/usage in the Spanish of Málaga. IULC Working Papers, 14(2).

Zimmer, T. 2011. El español hablado por los afrocostarricenses: estudio lingüístico y sociolingüístico. Kassel university press $\mathrm{GmbH}$. 
Zhou, X., Espy-Wilson, C. Y., Boyce, S., Tiede, M., Holland, C., \& Choe, A. 2008. A magnetic resonance imaging-based articulatory and acoustic study of "retroflex" and "bunched" American English/r. The Journal of the Acoustical Society of America, 123(6), 4466-4481. https://doi.org/10.1121/1.2902168 